with gabbro margins and syenite in its centre. This dyke could be followed over at least $25 \mathrm{~km}$ and occurs north of Geologfjeld where A. Weidick already noted its presence (see Emeleus \& Harry, 1970, p. 16), and on G. F. Holm Nunatak.

Finally, observations on the great Gardar swarm around Narssarssuaq and Qagssiarssuk showed that in the densest parts of the swarm the dykes take up to $16 \%$ of the space perpendicular to their trend.

\title{
References
}

Emeleus, C. H. \& Harry, W. T. 1970: The Igaliko nepheline syenite complex. General description. Bull. Gronlands geol. Unders. 85 (also Meddr Gronland 186, 3) 115 pp.

Walton, B. J. 1965: Sanerutian appinitic rocks and Gardar dykes and diatremes, north of Narssarssuaq, South Greenland. Bull. Gronlands geol. Unders. 57 (also Meddr Grønland 179, 9) 66 pp.

\section{HEAT FLOW INVESTIGATIONS IN THE NARSSAQ AND IVIGTUT AREAS}

\section{Bjarne Leth Nielsen}

Temperature measurements in drill holes have been carried out in the Ivigtut area and in the Ilímaussaq intrusion near Narssaq as the start of a general heat flow investigation in South Greenland. As this kind of work has not previously been done in Greenland and heat flow data from arctic areas are still very few it is hoped that the results will contribute to a better understanding of world-wide heat flow patterns and their relationship to major tectonic provinces.

The apparatus used, borrowed from the U. S. Geological Survey, consisted of a thermistor probe connected to a Wheatstone bridge at the surface where the thermistor resistance values were compensated. Measurements were taken at $10 \mathrm{~m}$ intervals both upwards and downwards and the mean values plotted in the temperature profiles.

In the Ivigtut area two drill holes were measured - Dh M $(500 \mathrm{~m})$ and $\mathrm{Dh} \mathrm{O}(200 \mathrm{~m})$. They are both situated in the Ivigtut valley. The cores consist of Ivigtut gneiss reworked during the Ketilidian. The four holes measured in the llímaussaq intrusion are Dh 1 (176 m), Dh $37(450 \mathrm{~m})$ and Dh $38(405 \mathrm{~m})$ on Kvanefjeld, and Dh I (197 m) in the Narssaq Elv valley. These holes were drilled during the exploration for uranium in the area. The cores consist mainly of radioactive nepheline syenites.

The temperature profiles for the six holes are shown in fig. 5. At the moment 

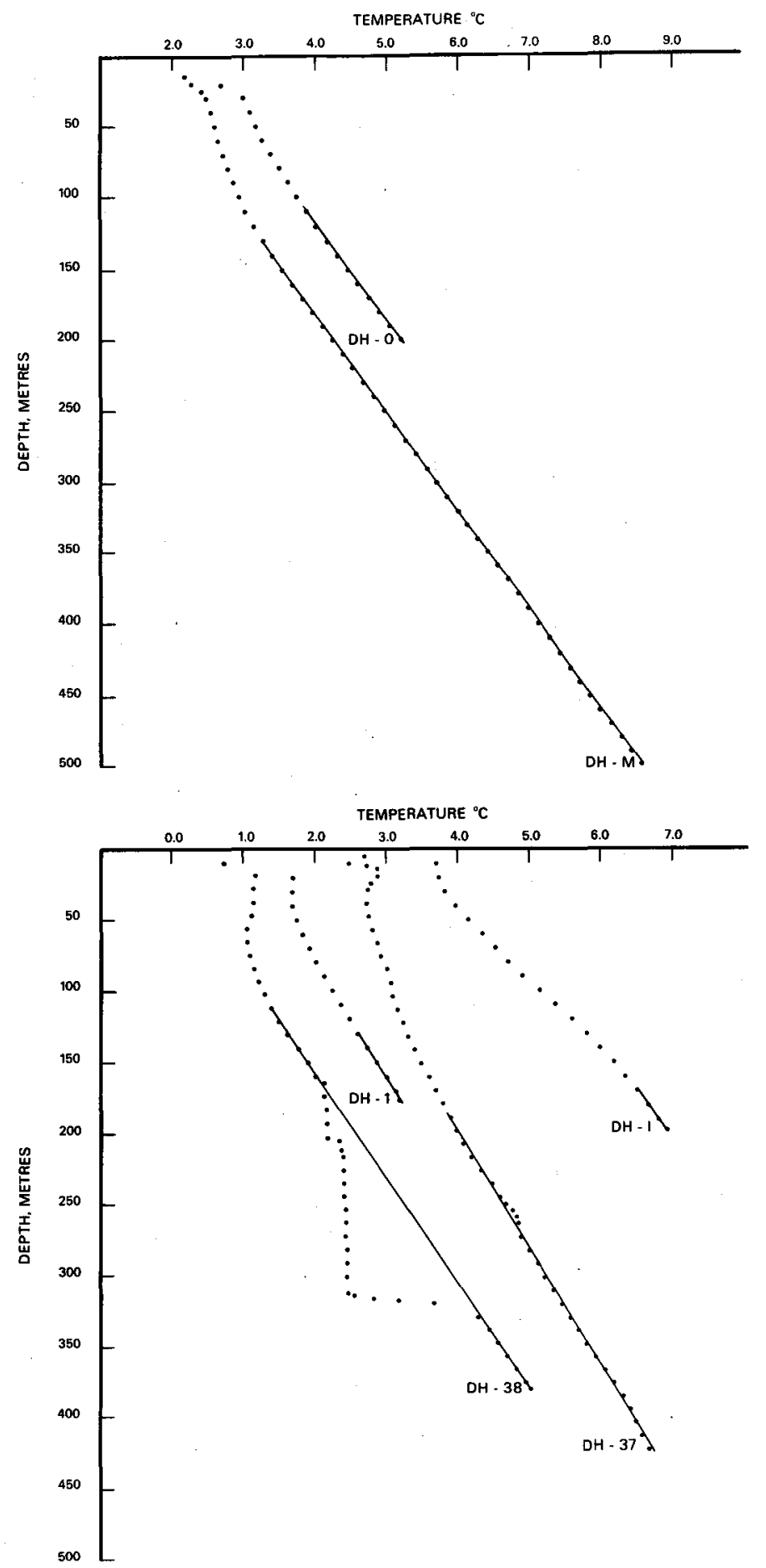

Fig. 5. Temperature gradients from the Ivigtut area and the Ilímaussaq intrusion. 
no corrections for topography have been calculated. The approximate temperature gradients found are:

\author{
Ivigtut: $1.5^{\circ} \mathrm{C} / 100 \mathrm{~m}$ \\ Kvanefjeld: $1.3^{\circ} \mathrm{C} / 100 \mathrm{~m}$ \\ Narssaq Elv valley: $1.9^{\circ} \mathrm{C} / 100 \mathrm{~m}$
}

The portion of the curves corresponding to the upper $100-150 \mathrm{~m}$ of the holes indicates a climatic amelioration during the last century.

The amount of heat conducted from the mantle and the crust, the heat flow, is the product of the temperature gradient and the thermal conductivity of the rocks. The world average heat flow is about $1.5 \mu \mathrm{cal} / \mathrm{cm}^{2} \mathrm{sec}$. Measurements of thermal conductivity have not yet been made on the cores and therefore it is not possible at the moment to present any heat flow results from SW Greenland. The Ivigtut values are expected to be slightly lower than the world average due to its position in a Precambrian shield. On the other hand the heat flow values from Ilímaussaq should be higher than the values from the Ivigtut gneiss because of radioactive heat generation in the $\mathrm{U}$ - and Th-bearing nepheline syenites. With known average radioactive concentrations and a "background", heat flow comparable to the basement values in Ivigtut, it may be possible to estimate the thickness of the radioactive Ilímaussaq rocks.

If the rock types in the cores from Ivigtut and llimaussaq have about the same conductivity, the temperature gradient in the high radioactivity Ilímaussaq should be steeper than in Ivigtut. This is found not to be the case. Explanations for this can only be tentative. If the amount of heat conducted from the mantle is assumed to be the same in the two areas, then the heat generated in the crust below a shallow Ilímaussaq intrusion must be less than is general elsewhere suggesting that Ilímaussaq is underlain by a basic layer of very little radioactivity; such a supposition is relevant not only to the regional heat flow but also to the evolution of the Gardar magma.

\title{
FIELD MEASUREMENTS OF THORIUM AND URANIUM IN LUJAVRITES FROM THE ILÍMAUSSAQ INTRUSION
}

\section{Poul Sørensen}

During last summer 3388 field measurements of the thorium and uranium content of the lujavrites from the Ilímaussaq intrusion were carried out with a portable spectrometer (Løvborg, 1967; Løvborg et al. 1968; Løvborg et al. in press) consisting of a scintillation detector and a single-channel pulse-height analyser. Within selected small areas measurements were made at the joints of a $1 \mathrm{~m}$ grid. 